\title{
Pulling of Hair While Sleeping: a Pediatric Case
}

\author{
Uykuda Saç Koparma: Bir Pediyatrik Olgu \\ Işık GÖRKER, ${ }^{1}$ Serap KARASALİHOĞLU, ${ }^{2}$ Levent ÖZTÜRK ${ }^{3}$ \\ Departments of ${ }^{1}$ Child and Adolescent Psychiatry, ${ }^{2}$ Child Health and Pediatrics, ${ }^{3}$ Physiology, \\ Medical Faculty of Trakya University, Edirne
}

Submitted / Başvuru tarihi: 26.08.2008 Accepted / Kabul tarihi: 08.01.2009

Trichotillomania, defined as an irresistible urge to pull and pluck one's own hair, is categorized as an impulse control disorder not otherwise specified in DSM-IV-TR. This behavior is performed in response to a number of emotions such as increasing temper or anxiety and gives resultant tension relief. Our case is an 11-year-old boy who showed signs of pulling his hair overnight and bedwetting when he was sleeping. Polysomnography was performed on him overnight during sleep to differentiate epileptic discharge, for a differential diagnosis. The results were within normal limits. The initial diagnosis of trichotillomania was discussed and we concluded that it would be more appropriate to evaluate the case under the diagnosis of parasomnia.

Key words: Trichotillomania; sleep; parasomnia; polysomnography; child.
Kişinin kendi kılını karşı konulamaz bir şekilde çekip koparması olarak tanımlanan trikotilomani, DSM-IV-TR'da Başka Türlü Adlandırılamayan Dürtü Kontrol Bozuklukları başlığı altında sınıflandırılmaktadır. Bu davranış, artmış öfke ve kaygı gibi duygular nedeni ile ortaya çıkan gerilimi ortadan kaldırmak için yapılmaktadır. Olgumuz, tüm gece boyunca uyurken saçını koparma ve altını ıslatma bulguları gösteren 11 yaşında erkek çocuğuydu. Ayırıcı tanı için olgumuza tüm gece süresince uyku sırasında polisomnografi uygulanarak, epileptik deşarjların ayırt edilmesi amaçlandı. Sonuçlar normal sınırlarda bulundu. Trikotilomani ön tanısı tartışıldı. Trikotilomaninin parasomni tanısı adı altında değerlendirilmesinin daha uygun olacağı sonucuna varıldı.

Anahtar sözcükler: Trikotilomani; uyku; parasomni; polisomnografi; çocuk.
The term trichotillomania is a combination of the Greek words thrix (hair), tillein (pulling) and mania (madness). It was first defined by Hallopeau in 1889 as 'an irresistible urge to pull one's hair, eyebrows, eyelashes, pubic hair or facial hair. ${ }^{[1-3]}$ In DSM-IV, it is classified under the category of Impulse Control Disorders Not Otherwise Specified, while in ICD-10, it is classified under Habit and Impulse Disorders in the group of Behavioral Syndromes Associated With Psychological
Disturbances and Physical Factors. ${ }^{[4,5]}$ Trichotillomania is a psychopathology with multidimensional etiology. Any stress factor, like the divorce of parents, birth of a sibling, sibling rivalry or moving into a new house may trigger the onset of this disorder. Psychodynamically, it is explained that trichotillomania is seen in children who could not complete the separation-individuation process or who experience emotional deprivation. Trichotillomania might be comorbid with depression,

Presented at the 18th World Congress of The International Association for Child and Adolescent Psychiatry and Allied Professions (IACAPAP), April 30 - May 3, 2008, İstanbul, Turkey (18. Uluslararası Çocuk ve Ergen Psikiyatrisi Kongresi'nde sunulmuştur, 30 Nisan- 3 Mayıs 2008, İstanbul, Türkiye).

Correspondence (IIletişim adresi): Dr. Işık Görker. Trakya Üniversitesi Tıp Fakültesi Çocuk ve Ergen Psikiyatrisi Anabilim Dalı, 22030 Edirne. Tel: 0284 - 2357641 /1176 Fax (Faks): 0284 - 2353891 e-mail (e-posta): isikgorker@trakya.edu.tr

๑) Trakya Üniversitesi Tıp Fakültesi Dergisi. Ekin Tıbbi Yayıncıık tarafından basılmıştır. Her hakkı sakıdır.

(c) Medical Journal of Trakya University. Published by Ekin Medical Publishing. All rights reserved. 
anxiety disorders, obsessive compulsive disorder and disruptive behavior disorders. ${ }^{[6,7]}$ The prevalence of TTM is probably underestimated because of the secretiveness that is a characteristic of the disorder. However, it is suggested to be $<1 \%$ among children and adolescents. ${ }^{[6]}$ Trichotillomania is more frequent in two age groups, namely early childhood and early adolescence. ${ }^{[8]}$ In studies with children there was no gender difference in terms of frequency. ${ }^{[6,9]}$

According to the DSM-IV-TR criteria, trichotillomania is defined as an increasing sense of tension, from which pleasure and relief are found from pulling the hair. However, most of the cases do not meet these criteria. ${ }^{[8,10]}$ Children, especially, might deny the tension and pleasure phenomena. Epidemiological studies also support this statement. ${ }^{[6,9]}$ A person should be awake to meet trichotillomania diagnostic criteria. Because the pulling of hair while sleeping does not meet this criterion, it is our aim to discuss our case presented in this paper in terms of diagnostic evaluation.

\section{CASE REPORT}

Our case was an 11-year-old boy who is the first of two children. He had a seven-year-old brother. He was in the fifth grade. He applied with his mother to the outpatient clinic of Child and Adolescent Psychiatry Department.

According to his mother's report, he had been pulling/plucking his hair on the right frontal part of his head for one year and he had been bed-wetting since infancy. When asked, he reported that he did not know he had been pulling his hair, and that he did not have any such behavior when he was awake. It was noticeable that he was pulling his hair on the right frontal part of his head; a bald spot was observed on his head. The mother reported that at first she coincidentally observed his pulling behavior and then she started to check him all the time, seeing that he pulls his hair every night. He rarely woke himself to urinate; he was generally in a deep state of sleep and for this reason he could not wake up during the night so he wet his bed.

He had a nuclear family composed of mother, father and two children. After the marriage, the mother got pregnant willingly. Her pregnancy was normal. The baby was full-term and a vaginal labor was conducted. He had no history of postnatal trauma or illness. He was breastfed for the first eight months. He started to sit for the first time when he was eight months old and to walk when he was 12 months old. He started to talk when he was 18 months old. He had his toilet training in the 24th month when he started to pronounce defecation. However, he did not have his toilet training for urination. He developed measles and varicella during his childhood. He did not have any history of febrile or nonfebrile convulsions.

The mother was a 30-year-old housewife. She graduated from primary school. According to her report, she did not have any problems in her relationship with our case. She was responsive towards her children. She did not have any medical problems.

The father was a 35-year-old farmer. He graduated from primary school. He was reported to be a responsive father. He did not have any medical problems.

It was reported that the parents did not have any marital discord.

In his psychiatric examination, the case looked his stated age with plain and clean clothes. He looked calm. He had eye contact during conversation, responded to questions appropriately, and talked spontaneously if necessary. He was attentive to his surroundings. His mood was assessed to be euthymic. His time and place orientation was normal. His attention and memory examination was normal. No thought or perception disturbances were identified. When asked, it was learnt that he was successful at school and that his relationships with peers were good. The psychometric evaluation revealed that his IQ was in the normal range.

A computerized polygraphic sleep examination was conducted on our case in a sleep laboratory. In this examination, by using 10-20 System of Electrode Placement, a 16-channel electroencephalography (Fp1F7, F7-T3, T3-T5, T5-O1, Fp1-F3, F3-C3, C3-P3, P3-O1 on the left side, and Fp2-F4, F4-C4, C4-P4, P4-O2, Fp2-F8, F8-T4, T4-T6, T6-O2 on the right side) was performed simultaneously with standard polysomnography. Polysomnography included recordings from two central EEG channels (C3-A2 and C4-A1), two electrooculography (left and right EOG), chin electromyography (EMG) for sleep staging, and nasal cannula, thoracic and abdominal movements by strain gauges, snoring, arterial oxygen saturation by pulse oximeter, body position, leg movements. Sleep staging was performed by 30 second epochs according to the standard criteria. ${ }^{[11]}$ This type of recording montage was preferred in order to demonstrate possible epileptiform discharges or other paroxysmal events during sleep. We failed to find any evidence for epileptiform discharges during hair-plucking episodes. It was observed that hair pulling occurred during superficial NREM period. Imipramine $50 \mathrm{mg}$ was prescribed and behavioral techniques were applied over a period of eight weeks for his primary enuresis nocturna treatment. It was treated in two months. There was a decrease in hair pulling during sleep. It is suggested that Imipramin changes the quality of sleep and decrease anxiety.

\section{DISCUSSION}

This is the first report of a boy pulling and plucking his hair while he is asleep. Because, in DSM-IV-TR, trichotillomania is considered to be an impulse control disorder while awake, pulling hair during sleep can be categorized as a rhythmic movement disorder in sleep. Rhythmic movement disorder that occurs during sleep 
is categorized under parasomnia. It usually occurs in the NREM period of sleep. These movements can lead to soft tissue damage, albeit rarely. ${ }^{[12]}$ It was found to be associated with depression in the mother and low family socio-economic status. Sleep-related rhythmic-movement disorder, like body-rocking is usually considered a pleasant self-soothing behavior associated with sleep onset, but it has been suggested that it reflects an unbalanced mother-child relationship. ${ }^{[13]}$ Psychodynamically, it is suggested that emotional deprivation in a child's relationship with his/her mother in the early years, plays a role in the occurrence of trichotillomania and that there is an intense conflict between mother and child. ${ }^{[14]}$ It is interesting that conflict is present in the mother-child relationship and that behavior relieves the person in both disorders. Stereotypical paroxysmal events (hair-pulling in this case) during sleep may be manifestations of nocturnal seizures. ${ }^{[12]}$ Therefore, a formal polysomnographic study with a full seizure montage is indicated in these cases with atypical histories. This time, approximately eight-hour recordings showed electrical activity of the brain within physiologic limits. Parasomnias are defined as undesirable behavioral or experiential phenomena that occur predominantly during sleep. ${ }^{[15]}$ Parasomnias usually occur in the first third of the sleep cycle and are common in childhood. A common classification is made according to the sleep state of origin: rapid eye movement sleep parasomnias and non-rapid eye movement parasomnias. Hair pulling occurred during NREM sleep in our patient, but we failed to find trichotillomania as any kind of sleep disorder in the International Classification of Sleep Disorders Manual which classifies all sleep disorders (ICSD-2). Our case was not reported to have any stress factors in his life. He does not have any comorbid disorders, except primary enuresis nocturna. All clinical studies, except one, report that cases have trichotillomania while they are awake. In the report of an adult case, similar to our case, trichotillomania was found to occur during NREM period of sleep. ${ }^{[16]}$

During sleep, children and adolescents might experience extraordinary behaviors, like confusional arousal state, sleepwalking, night terror, nightmare, enuresis, and bruxism and these are grouped under sleep disorders called parasomnias. During childhood, parasomnias are observed usually during the NREM period of sleep. ${ }^{[12,17]}$ The pulling of hair while asleep and primary enuresis nocturna complaints of our case were assessed as parasomnias.

\section{REFERENCES}

1. Aljabre SH. Trichotillomania: a trichotillosis, a trichotillotic, or a tic trichotillosis. Int J Dermatol 1993;32:823-4.

2. Hamdan-Allen G. Trichotillomania in childhood. Acta Psychiatr Scand 1991;83:241-3.

3. Hussain SH. Trichotillomania. Two case reports from a similar cultural background. Psychopathology 1992;25:289-93.

4. American Psychiatric Association. Diagnostic and statistical manual of mental disorders. 4th ed. Washington: American Psychiatric Pub; 2000.

5. World Healt Organization. The ICD-10 classification of mental and behavioural disorders: clinical descriptions and diagnostic guidelines. 1st ed. Geneva: World Health Organization; 1992.

6. Tay YK, Levy ML, Metry DW. Trichotillomania in childhood: case series and review. Pediatrics 2004;113:e494-8.

7. Görker I. Çocukluk çağı trikotilomani'sinde davranış, semptom ve komorbiditenin incelenmesi. [Yan Dal Uzmanlık Tezi] İstanbul: İstanbul Üniversitesi Tıp Fakültesi; 1997.

8. Bruce TO, Barwick LW, Wright HH. Diagnosis and management of trichotillomania in children and adolescents. Paediatr Drugs 2005;7:365-76.

9. Woods DW, Flessner C, Franklin ME, Wetterneck CT, Walther MR, Anderson ER, et al. Understanding and treating trichotillomania: what we know and what we don't know. Psychiatr Clin North Am 2006;29:487-501.

10. King RA, Scahill L, Vitulano LA, Schwab-Stone M, Tercyak KP Jr, Riddle MA. Childhood trichotillomania: clinical phenomenology, comorbidity, and family genetics. J Am Acad Child Adolesc Psychiatry 1995;34:1451-9.

11. Carskadon MA, Rechtschaffen A. Monitoring and staging human sleep. In: Kryger MH, Roth T, Dement W, editors. Principles and practice of sleep medicine. 4th ed. Philadelphia: Elsevier Saunders; 2005. p. 1359-77.

12. Rosen GM, Ferber R, Mahowald MW. Evaluation of parasomnias in children. In: Lewis M, Dahl RE, editors. Child and adolescent psychiatric clinics of North America. Philadelphia: W.B. Saunders Company; 1996. p. 601-16.

13. Spitz RA. Autoerotism-Some empirical findings and hypotheses on three of its manifestations in the first year of life. Psychoanal St Child 1949:3;85-120.

14. Galski T. Hair pulling (trichotillomania). Psychoanal Rev 1983;70:331-46.

15. Mahowald MW, Bornemann MA. NREM sleep arousal parasomnias. In: Kryger MH, Roth T, Dement W, editors. Principles and practice of sleep medicine. 4th ed. Philadelphia: Elsevier Saunders; 2005. p. 889-96.

16. Murphy C, Valerio T, Zallek SN. Trichotillomania: an NREM sleep parasomnia? Neurology 2006;66:1276.

17. Brown LW. Sleep and epilepsy. In: Lewis M, Dahl RE, editors. Child and adolescent psychiatric clinics of North America. Philadelphia: W.B. Saunders Company; 1996. p. 701-14. 